EGU2020-19598

https://doi.org/10.5194/egusphere-egu2020-19598

EGU General Assembly 2020

(c) Author(s) 2020. This work is distributed under

the Creative Commons Attribution 4.0 License.

\title{
Cosmogenic burial dating of in cave-deposited alluvium: unravelling long-term incision rates and complex speleogenesis in multi-level cave systems
}

Gilles Rixhon ${ }^{1}$, Didier L. Bourlès², Régis Braucher ${ }^{2}$, Alexandre Peeters ${ }^{3}$, and Alain Demoulin ${ }^{3,4}$

${ }^{1}$ Ecole Nationale du Génie de l'Eau et de l'Environnement de Strasbourg (ENGEES) \& LIVE UMR 7362 - CNRS, Strasbourg, France (gilles.rixhon@live-cnrs.unistra.fr)

${ }^{2}$ CEREGE, Aix-en-Provence, France

${ }^{3}$ Dept of Physical Geography and Quaternary, University of Liège, Belgium

${ }^{4}$ FSR-FNRS, Brussels, Belgium

Multi-level cave systems record the history of regional river incision in abandoned alluvium-filled phreatic passages which, mimicking fluvial terrace sequences, represent former phases of fluvial base-level stability. In this respect, cosmogenic burial dating of in cave-deposited alluvium (usually via the nuclide pair ${ }^{26} \mathrm{Al} /{ }^{10} \mathrm{Be}$ ) represents a suitable method to quantify the pace of long-term river incision. Here, we present a dataset of fifteen ${ }^{26} \mathrm{Al} /{ }^{10} \mathrm{Be}$ burial ages measured in fluvial pebbles washed into a multi-level cave system developed in Devonian limestone of the uplifted Ardenne massif (eastern Belgium). The large and well-documented Chawresse system is located along the lower Ourthe valley (i.e. the main Ardennian tributary of the Meuse river) and spans altogether an elevation difference exceeding $120 \mathrm{~m}$.

The depleted ${ }^{26} \mathrm{Al} /{ }^{10} \mathrm{Be}$ ratios measured in four individual caves show two main outcomes. Firstly, computed burial ages ranging from $\sim 0.2$ to $3.3 \mathrm{Ma}$ allows highlighting an acceleration by almost one order of magnitude of the incision rates during the first half of the Middle Pleistocene (from $\sim 25$ to $\sim 160 \mathrm{~m} / \mathrm{Ma}$ ). Secondly, according to the relative elevation above the present-day floodplain of the sampled material in the Manants cave $(<35 \mathrm{~m})$, the four internally-consistent Early Pleistocene burial ages highlight an "anomalous" old speleogenesis in the framework of a gradual base-level lowering. They instead point to intra-karsting reworking of the sampled material in the topographically complex Manants cave. This in turn suggests an independent, long-lasting speleogenetic evolution of this specific cave, which differs from the per descensum model of speleogenesis generally acknowledged for the regional multi-level cave systems and their abandoned phreatic galleries. In addition to its classical use for inferring long-term incision rates, cosmogenic burial dating can thus contribute to better understand specific and complex speleogenetic evolution. 